\title{
METAPHOR AND MYTH AS ELEMENTS OF ARTISTIC-LANGUAGE
}

\begin{abstract}
The article is devoted to analysis of the artistic culturestructure. Artistic culture has developed its main structural elements that provide a certain logic of artistic thinking and artistic creativity and which are the basis of any work of art. These structural elements - rhythm, intonation, metaphor, myth (as a way of action organizing, as a prototype of composition), archetypes and archetypal symbols - are the main artistic means that "work" in all types of art, while defining the specifics (due to their dominance) of the each one of them.

Keywords: myth, metaphor, artistic culture, structural elements, semiotics, artistic thinking.
\end{abstract}

Formulation of the problem. The further culture goes in the way of understanding itself, the more complicated and artificial its models, norms and criteria become, the more hidden its sources, initial meanings, that once gave rise to the world's views, norms and standards known to us. When a culture loses its original meaning, it becomes conservative and inertial, more vulnerable to crises or anti-cultural movements. Culture sags in the air, out of that nutritious root, the soil on which it grows and which gives it strength for development. To understand the characteristics and direction of the cultural form we need to refer to its origins. Meaning those existential phenomena which are realized and rooted in the consciousness (or rather in the subconscious) and become the basis of cognitive attitudes, images and views of the world, and underlie human creativity.

Analysis of research and publications. The problem of metaphor is devoted works by such researchers as N. Arutjunova, G. Vico, G. Hegel, E. Cassirer, N. Fraj. The topic of myth is considered in works of such researchers as R. Antes, I. D'jakonov, A. Losev, V. Toporov.

Purpose of the article. The purpose of the study is devoted to the problem of connection between myth and signification regime of metaphorin the meaning of art.

Exposition of the main material of the study. They generate specific highly ordered structures of cognitive activity, such as metaphor, myth, and archetypal images and symbols. On the one hand, all these existential phenomena are the subject of practical interest and scientific cognitive activity. But the "Earth", for example, can be treated not only as a dead matter, a source of fertility, but also as a "Mother of humanity". And this attitude will be not just a poetic metaphor, but also a big insight. This mythological image of the Earth passes through all cultural epochs and feeds their creative potencies. Thus, analyzing the ancient worldview V.N. Toporov notes this relationship with the mythological image of the earth and the ancient understanding of the earth as wisdom: "The earth is always isolated, alone, like every woman who is preparing to be a mother. Abandoned, sad and joyful, she is the only bearer of integrity, completeness and perfection in a number of generations of her children; she is an accomplice of life, turns on herself many times to create life from herself. The earth is capable of giving birth ... as a form of selfdeepening of life, it is self-sufficient and therefore free, it is initially feminine .... and multiples" [13, p. 163].

Archetypal symbols are never exhausted, are not removed by culture, they live in it, nourishing it from within, or directly spiritualizing it, giving it a creative impulse. Culture is only viable when a deep meaning is seen in its settings and methods, which in each cultural epoch is expressed unilaterally, incompletely, inaccurately, remaining a source of creative potential and unlimited field of creativity. For example, the phenomenon of light has such inexhaustibility. One of the main characters of ancient mythology is Prometheus, who stole fire from the gods and gave it to people. Fire radiates light. The light for the ancient man is one of the primary materials of the universe and the light of wisdom. After all, as A.F. Losev wrote, for the ancient man "... the whole universe is light ... And then the task of wisdom consists of awareness of the world's images of the universe. The images of things are the content of things; the content of things is the content of concepts. To operate with concepts is to operate with the very images of things" [10, p. 46].The game of light and shadow was widely used by ancient sculptors and architects as a kind of artistic device [10, p. 57].

The entire European philosophy and theology from the Gnostics to the Neo-Platonists - Plotinus, Proclus, Philo of Alexandria - through Nicholas of Kuzansky to Kant are filled with deep interest in the subject of "light-shadow" . As for art, the concept of light is fundamental in the development of European art styles: it is all built on the contrast of light and darkness.

In contrast to the culture of the West, the "shadow" as the core meaning of culture does not have the negative content that has become established in Europe. "Unlike European philosophy and aesthetics, writes E.V. Zavadskaya, - those who understand the shadow as the dark, in the negative meaning, sides of things or a human, Chinese aesthetics understand the shadow as a good sign of the connection of the phenomenon and the essence of the world, as emanations of the absolute [7, p. 224].

The archaic symbols and archetypes that play a large role in art, in science, in human psychology are also the fundamental foundations of culture: it is a world tree, a world egg, a wheel, a circle, a snake, a dragon etc. Thus, the image of the world tree, almost universal for all nations, embodied a generalized concept of the world. The world tree is a pillar of the signally organized Cosmos as a counterbalance to unsigned Chaos. The world tree included the main oppositions and expressed the result of the global formation: sky - earth, upper - lower, past present - future, three parts of the body etc.

In the cultural development of mankind, the concept of the world tree left, according to V.N. Toporov [14], the traces in numerous cosmological, religious ideas, which are reflected in texts, poetic images, visual arts, architecture, planning of settlements, ritual, social and economic structures. To the same extent, the mythopoetic image of the world egg, from which the Universe, or some personified creative power, is transmitted through all ages, through archaic, semi-scientific and scientific ideas about the structure of the world; and today this image occupies a significant place in cosmological theories.

Other well-known archetypes are myths. We are talking about the archetypical nature of the main spiritual, moral and social problems, conflicts, which Aristotle calls the myth of the ancient tragedy, modern literary critics, plot, and N. Frye [15] defines as literary modes. These are the conflicts of good and evil, love and hate, devotion and betrayal, wealth and poverty, strength and weakness, power and submission etc. Myths provide the meaning of 
human life and offer patterns of behavior and forms of conflict resolution. And these ensure the viability of mythical and fairy archetypes that have lived for thousands of years and fertilize artistic fantasy.

Metaphor, as an artistic forming tool, is by far the most researched, not only from the point of view of its artistic and aesthetic value, but also from the point of view of the development of cognitive science, engaged in the study of various aspects of human consciousness. The metaphor was seen as the key to understanding the fundamentals of thinking and the processes of creating not only a nationally specific vision of the world, but also its universal image. The metaphor is explored in various terminological systems, in children's speech and didactic literature, in various types of media, in the language of advertising, in titels, in sports, and even in the language of the deaf and dumb [12].

Metaphor (Greek.Metaphora - transfer) is the transfer of the value of one object to another with the realization (often uncertain) of their difference, expressed in verbal form as an image. That is why many researchers point to the unity of image, word and metaphor in the development of human thinking. So the metaphor is the means by which the word-image is created. The wordimage is also the basis of the myth, and therefore the mythology acts as a product of speech.

It is clear that such a metaphor, as it is called the "basic metaphor", is primarily a linguistic phenomenon. In contrast to the individual metaphor of artistic speech, the ancient "basic" metaphor became a consequence of necessity and in most cases was obliged by its origin not so much to transfer from one concept to another, as to a more precise definition of concepts.

One of the first researchers of G.Vico'smetaphor, defines it as the most important of the paths of "poetic logic", which "provides the soulless things with feelings and passions". "After all, the first poets endowed bodies with being of spiritualized substances that owned only those things they were capable of, that is, feelings and passion. This way the poets created myths from bodies, and each metaphor turned out to be a little myth. Therefore, our criticism gives us the following position regarding the times when metaphors originated in language: all metaphors that define the abstract work of the mind by means of analogy with bodies should have arisen at a time when philosophy began to become less rough. This is proved by the fact that in all languages necessary for cultural arts and for the secret sciences, words have a peasant origin. It is fair to observe that in all languages a significant part of expressions is transferred onto inanimate things from the human body, its parts, from human feelings and from human passions" [4, p. 146].

So, according to G.Vico, the metaphor, which was considered to be the ingenious invention of the writers, was a necessary means of expressing all the first "poetic nations", and by its origin owned its true meaning. But when, with the development of the human mind, were invented words that defined abstract forms or generic concepts that were encompassing their species or combining parts with their whole, then such means of expression of the first peoples became transferal. Therefore, the idea that prose writers were real language, and the language of poets was not real, and they first spoke in prose and only then in verses, was false. Thus, if a metaphor in a general sense should not be viewed as a certain phenomenon of language, but as one of the constitutive conditions for the existence of language, then for its understanding one should turn to the basic form of creating concepts in language. In the end, they arise in the process of the act of concentration, compression of sensory experience, creating the necessary prerequisites for the formation of each language concept. Suppose that this concentration is realized in different senses and by various means, so that in two perceptual complexes the same moment is singled out as "essential", internally significant and semantic, then there is a relationship between these two complexes and a close relationship that can be created only by language. After all, that which is not named does not exist in the language at all, and everything that is equally named seems to be absolutely the same. The uniformity of the signs enshrined in the word requires that other aspects of the concepts recede into the shadow and, in the end, lead to their disappearance. In this case, the part replaces the whole, becomes and acts as a whole. A language treats content in the same way, which seem different from the point of view of our direct sensory perception or logical classification, so that every statement that is valid for one content can be transferred to another. Each characteristic feature that gives impulse to the formation of concepts and definitions, simultaneously causes the merging of the corresponding subjects.

"If the image of lightning in the mirror of the language is "serpentine", it means that the lightning has become a snake, and when the sun is called "what flies in the sky, "it is thus represented as an arrow or a bird. portrayed with the head of a falcon. There are no simply "abstract" definitions, each word immediately turns into a specific mythological image, a god or a demon [12].

In the further development of the spirit, this close and necessary connection begins to weaken and break. In the course of language development, the word becomes just a sign of the concept. However, the figurative expression of the word acquires independence in the field of art and poetics. The figurative expression makes clear the evident meaning in the form of a related external phenomenon and does so in such a way that it does not create a task that requires a solution, but figurativeness through which transparently shines the content of the presented information. G.V.F. Hegel, who turns to the metaphor in connection with the study of the lowest, from his point of view, historical stage of the development of art - a symbolic art form, follows the tradition established by Aristotle - consider the metaphor as one of the poetic paths: "It (metaphor) is an abbreviated comparison, since it does not compare the image and content with each other, but gives us only an image, omitting the actual content of the latter, but only due to the connection in which the image is given, does the metaphor in the image itself immediately discern the meaning that is really meant, although it is not explicitly indicated. Since the content that has acquired a figurative form is found only from the context, the value expressed in the metaphor can impinge on the value of not an independent, but only an accompanying artistic image. As for the metaphor, it is even more true that it can only act as an external decoration of an independent artistic work in itself" [5].

If Hegel, like all representatives of the philosophical classical rationalism, belittled metaphor as an inadequate and non-obligatory form of the expression of truth, then philosophical irrationalism sought to give all knowledge to the metaphor, removing truth from it. Different versions and reflections of this approach to the role of metaphor in cognition are found in all philosophical concepts, marked by the stamp of subjectivism, anthropocentrism, intuitivism, interest in mythopoetic thinking and national pictures of the world. But at the same time, E. Cassirer founded a productive scientific direction related to the study of symbolic forms in human culture. He expanded the scope 
of the theory of knowledge through the study of logical thinking, reflected in language, mythology, religion, art, and largely led to the attraction of interest in the metaphor as a form of thinking. The significant scientific potential of the last century on the study of metaphor [8] allows us to significantly deepen and expand its understanding as an artistic form-building tool, to understand that metaphor is an organic component of an artistic (poetic) text and its use in other types of discourse is connected with the need for the presence of elements of poetic thinking and imaginative vision of the world.

The metaphor is related to the poetic discourse, according to N.D. Arutiunova, through the following features: 1) merging in its image and content; 2) contrast with the trivial taxonomy of objects; 3) categorical shift; 4) the actualization of "random links"; 5) irreducibility to a literal paraphrase; 6) syntheticity, diffusion of meaning; 7) the permissibility of various interpretations; 8) the absence or lack of motivation; 9) appeal to the idea, but not to knowledge; 10) selection of the shortest path to the essence of the object [2, p. 20].

The connection of metaphor with poetic notions, with fantasy, its imagery, made it possible to talk about the metaphor in painting, theater and cinema, which technique has evolved towards the use of indirect means of expression, symbolism. The transfer of metaphor to the soil of visual art led to a significant change in this concept, emphasizing its figurative nature and its transformation into a symbol.

The myth, as an artistic means, as a certain figurative structure also arose from the word. It is clear that what is meant is not a myth at all as a genre of literature, but the comprehension of the world and the emotional implantation of its phenomena. The myth belongs to the sphere of literature not as a genre, but only in the sense that it not only expresses the relationship of a person with an external phenomenon, but also (as opposed to an image) embodies it in verbal form, so in a well-known utterance and even a plot narration.

Perceiving the world around us, which always caused certain emotions, and trying to comprehend it (and this is impossible without generalization), a person faced certain difficulties. Firstly, he did not have sufficient linguistic means for expressing general concepts and he had to express the general through an individual one. So, in one of the archaic languages known to us, Sumerian, to say "kill," they said "to strike a head with a stick," although it was a killing with a sword; meaning to say "property", said "hand thing" instead, etc. In addition to the fact that the word could not express an abstract concept, it could also be multi-valued, combining meanings, united by both logical and emotional associations. Secondly, even if there are practical differences in the existing connections between phenomena, the connection between a part and the whole, or a similarity connection, or connection of a name with the object itself, etc., often acted as a causal relationship (especially if the collective experience was insufficient to identify a logical error).

Due to the fact that the social practice of the primitive man was rather limited, this gave rise to a third difficulty. Collective practical experience, whatever it may be, was accumulated by dozens and even hundreds of generations, therefore, although it had enough identified errors, it was quite reliable. For each primitive group, this experience was concentrated in the wisdom of the ancestors, in the unspoiled tradition that the elderly kept, so it could not be refuted by occasional individual observations. Therefore, understanding the facts of the external world was a matter of faith, and faith was not subject to verification and did not need it. As noted by the well-known researcher of the ancient Eastern culture, I.M. Diakonov, studies of archaic languages make it possible to reconstruct the principles of constructing judgment in the early epoch of human history. "Observations on ancient and archaic languages allow us to reveal almost the only present information about what means of generalizing information about the world were at the disposal of mankind in the early stages of its development. in reality is not indisputable, because we cannot reproduce the process of thinking of ancient people.

But the data of the language, with the help of which only general conclusions about the world could be created - which no doubt myths were - are of a relatively objective character and besides are at least partially contemporaries of the myths we study" [6, p. 11]. I.M. Diakonov uses the concept of "semantic rows" (for the first time the term was proposed by the linguistic school of N. Marr [6, p. 17]), which includes, above all, metaphor, metonymy, trope, the concepts more or less constantly interchangeable or associative related to each other in myth-making and wordcreation, and the conditionality of their connection from the point of view of modern logic may not be obvious enough, but in historical terms it is revealed as "metaphorical" or one of the "metonymic" associations.

Thus, semantic rows related to the feminine and masculine beginnings can be traced by I.M. Diakonov on the example of the Sumerian and Akkadian languages belonging to the Semitic branch of languages. In most ancient languages, the prolific "earth" is feminine and, accordingly, in myth, the goddess, and the deity of heaven is masculine; The exception is Egypt, which does not know the fertilizing rain (here the deity of the earth is male, and the deity of the sky is female); The designations of fertility (animal and plant) are often at the same time the designation of female charms, and simply female organs. On the contrary, the male principle is often referred to as a hand, a tree, a stick, a weapon. "Water" in the Sumerian language in the semantic row is next to "family", "father", "heir", but in the Pra-Aphrasian language "water" is associated with the concepts of "death" - "disease" "darkness" - "cold" - " night".

It is easy to see that such semantic associations are similar to those that arise in artistic creation. And there is nothing surprising in this: in art, as in language and in myth, generalization is achieved not through the abstract, but through the concrete and the individual, so that it is characteristic and contributes to the emergence of the necessary generalizing impression.

That which seems illogical, arbitrariness of the mythmaking fantasy, is explained by the fact that the understanding and generalization of the phenomena of the world is carried out in the myth by semantic emotionalassociative rows. An illustrative example is provided by Egyptologist R. Anthes [1, p. 38], talking about Egyptian mythological ideas that reflect on what sky is: the sky is a big cow, and its four legs are the four directions of the world; the sky is the goddess Nut, raised by the god Shu from the embrace of her lover, the god of the earth Hebe; the sky is the river along which boats of the sun, moon, and stars sail from east to west. And all this exists simultaneously, and not only in the lists contained in religious hymns and funeral ritual spells (Pyramid Texts), but also on the same image. However, there is no contradiction here, but the opposite: the more metaphors that highlight the main features of a phenomenon, the more precise and understandable this phenomenon becomes.

In parallel to understanding the world through the mythmaking, the process of developing the conceptual apparatus, as well as the division of the sphere of 
knowledge into the knowledge of the object as such and the attitude towards the object (which is not divided in myth-making), took place. Theoretical knowledge breaks with the myth, but artistic knowledge (art) should have used the same methods that mythmaking used, because he was not interested in the object as such, but only in an emotional, value-related attitude to the object. Since emotions are fundamentally impossible to express by their generalization in abstract concepts, art same as mythmaking, uses its ability to convey generalizations associatively through an individual, but individual not as a single, but as an artistic image with a significant number of emotional associations. Considering that we are talking about emotional associations of supraindividual meaning, it is clear that here semantic rows can and should be preserved, acquiring the character of poetic paths, that is, methods of using the word not in its basic, literal sense, but with the conscious purpose of identifying some signs or emotional associations of a concept, which usually expresses this word, or concepts expressed in a solid context. The semantic nature of the myth to a certain extent determines its second feature - narrative. In the conditions of syncretism of culture forms existence, the story and the action are combined: purely verbal forms of myth do not exist in primitive culture. The word had to be supplemented by a dramatization, a set of actions, a ceremony. Thus was created a mythical plot. In our opinion, it is necessary to distinguish between mythical and mythological plots, since the latter is part of certain ordered with the help of figurative, symbolic, poetic systems, texts that are known to us from the cultures of ancient civilizations. Ancient mythology becomes in these societies a unity of religious, artistic, and ritual representations, and on the basis of them is systematized, ordered, transformed into an integral system of spiritual representations that rule the complicated social life of ancient civilizations. Mythical plots (myths) are certain structures, that because of constant repetition, unite into a single whole, reproduction, the semantic basis of the myth with a specific act, which clearly reproduces the cognitive moment of human interaction with the outside world, man and society, man with another person. Therefore, the mythical plot as a certain integrity is a sacred story and always has to do with certain realities. It is through myth that a person becomes capable of combining actions into an event, reproducing an event, and, accordingly, fixing the flow of time in a certain structure, and to structure time combining events. Although the myth is non-historical in the modern understanding of history (because myth during playback actualizes the past event and the mythological consciousness perceives it directly), but without it, without this primary structure, neither mythology, nor literature, nor history could exist. An important place in the structural organization of any artistic image belongs to archaic symbols and archetypes. The most productive approach and weighty scientific groundwork on this issue was proposed by C.G. Jung, who developed the problems of analytical psychology based on the psychoanalytic concept of S. Freud. A significant contribution to the study of specific forms of archaic symbols and archetypes was made by structuralism.

Interest in structural and semiotic models of the creation and functioning of various cultural phenomena was primarily associated with the study of preliterate and unwritten cultures, and to a certain extent under the influence of structural semiotic linguistics. Analytical psychology and structuralism have come to the conclusion that archetypes, like symbols, play the role of specific thinking units, which have an intermediate logical status between certain sensual images and abstract concepts.
Thus, it is precisely structuralism that is credited with bridging the gap between the sensual and intelligible, which is characteristic of classical gnoseology. C.G. Jung believes that the original image, or archetype, is the preferred expression of the collective unconscious and such that it experiences not so much a personal as a collective effect. That is why it is equally proper for whole nations or epochs. The initial image is a deposition in memory, formed as a result of thickening, compaction of numerous processes similar to each other. It is, first of all, from the very beginning, a clot and, thus, it is a typical basic form of a known, always reproducible spiritual experience. That is why, as a mythological (sense-forming) motive, the initial image is always an effective and always reappearing expression that either awakens a certain spiritual experience or formulates it accordingly [12].

C.G. Jung notes, that perhaps the original image is a mental expression for a specific physiological and anatomical predisposition. If we take the view that a certain anatomical structure arose under the influence of environmental conditions on living matter, then the initial image, in its stable and widespread manifestation, corresponded to the same universal and sustainable external influence, and therefore must have the character of a natural law.

Thus, it would be possible to establish the relation of myth to nature (for example, the relation of solar myths to the daily sunrise and sunset, or to the change of seasons). But in this case, the question would remain open: why then is the sun and its changes not the direct and immediate content of the myth? However, the fact that the sun, moon, or meteorological processes get an allegorical form indicates the independent participation of the psyche in this work, and in this case the psyche can no longer be considered only a product of the reflection of environmental conditions. But from where would it even take its ability to acquire an independent point of view beyond all sensory perception? Where would its ability to detect a little more or different than confirmation of sensual impressions come from?

Therefore, according to C.G. Jung, we must recognize that this brain structure happened not only because of influential environmental conditions, but also because of peculiar, independent properties of living matter which is the law that given along with life. That is why these properties of the organism are, on the one hand, the product of external conditions, and on the other hand, the product of the purpose inherent in all living things. In accordance with this the initial image, on the one hand, must undoubtedly be attributed to the well-known, sensually perceived, always reproducible, and then always effective processes of nature, and on the other hand, and to the same extent, undoubtedly, it must be referred to the known inner inclinations of spiritual life and life in general. Organism contrasts a light with a new formation - the eye, and the spirit contrasts the processes of nature with a symbolic image, perceives the processes of nature as the eye perceives light. Just as the eye testifies to the peculiar and independent activity of living matter, so the initial image is an expression of personal and unconditional creative fortitude.

C. Levi-Strauss not only develops the scientific concept proposed by C.G. Jung on a richer empirical material, but also comes out in open debate with vulgar materialism and sensationalistic empiricism, which was never able to overcome the dualism of the ideal and the real, the abstract and specific. Levi-Strauss believes that the immediate perceptions do not boil down to either of these terms, nor do they lie here or there; in other words, they are already encoded by the senses as well as the brain, in the form of 
text, like any text, must be decoded in such a way that it can be translated into the language of other texts [9, p. 48]. Moreover, the physicochemical processes by which this original text was originally encoded are not significantly different from the analytical procedures that the mind uses in decoding. Ways and means of decoding are inherent in extremely high intellectual activity, since understanding leads to the development of intellectual processes, carried out already in the senses themselves. Vulgar materialism and sensualistic empiricism, C. Levi-Strauss observes, put a person in direct confrontation with nature, without realizing that the latter has structural properties that, although undoubtedly richer, do not differ significantly from those codes by which their nervous system decodes, or from the categories developed by the mind to return to the original structure of reality. To accept that the mind is able to understand the world only because the mind itself is a part and product of this world does not mean to become a mentalist or an idealist. It is daily confirmed that, trying to understand the world, the mind uses means that do not differ from those that have taken place in the world since the beginning of time.

"Structuralists were often accused of playing with abstractions that were not related to reality. I tried to show",-Levi-Strauss concludes, "that, far from being entertainment for sophisticated intellectuals, structural analysis, penetrating, reaches the mind only because his model already exists "inside the body" ... Following the path, which is mistakenly accused of being overly intellectual, structuralism opens and brings to awareness the deeper truths that already exist in a hidden form in the body itself; he reconciles the physical and the spiritual, nature and man, mind and the world, and guides to a single type of materialism, in accordance with the actual development of scientific knowledge. Nothing could be farther from Hegel and even Descartes, whose dualism we try to overcome, while at the same time observing his devotion to rationalism" [9, p. 353].

It cannot be claimed that the ideas of structuralism about the specifics of human sensuality are fundamentally new, because in a purely philosophical and epistemological aspect, they to some extent coincide with the materialistic approach proposed by L. Feuerbach and developed in Marxism, primarily in his work "Philosophical and Economic Manuscripts 1844" [11]. But structuralism reaches these general conclusions not through philosophical discourse, but through the analysis of specific forms of culture and art.

It is clear that the pragmatics of structuralism does not allow to be satisfied with these conclusions as final, does not require further research, including the involvement of research by psychologists, neuropsychologists, philosophers. The statement that "the eye doesnt just photograph objects: it encodes their distinctive characteristics," "the immediate data of sensory perception is not raw material ... from the very beginning they are distinctive abstractions of reality" [9, p. 350-351], just as the conclusions of the previous structural analysis are not fundamentally different from the statement: "The eye became the human eye in exactly the same way as its object became a public human object created by man for man. Therefore, feelings directly in their practice became theorists" [11]. If we take into consideration that between these statements almost 130 years of intensive scientific development, consciously focused on specific anthropological research, have been laid, then attempts to counter the historical-evolutionary approach of classical materialism to ethnological structuralism of modern philosophical anthropology are not sufficiently justified. Historical heterochronism must be supplemented today with synchronicity, which is only a moment of abstraction from the processes of formation in order to study the logic of internal organization, inherent in cultural phenomena. As to aesthetics, structuralism allowed to fundamentally modify the empirical base of aesthetic reflection, because classical and postclassical aesthetics was mainly based on art history, which in its turn was based on the study of classical art forms, subsequently transferring the basic concepts and categories to research and classifying prehistoric forms of culture and aesthetic human activity. That is why classical aesthetics in many aspects contributed to the assertion of the ideas about a prehistoric man, his abilities and capabilities that were unfounded or grounded only by speculative reflection. That is why aesthetics turned out to be unfavorable for integration into modern humanities.

Philosophical anthropology (in all its diversity) today gives grounds for a new development of aesthetic science, in terms of its ablility to organically integrate the achievements of twentieth century science into its context. Significantly expand the boundaries of its subject and be ready for fundamentally new humanistic conclusions. Returning to the question of archetypical symbols, it should be noted that they carry the same (or similar) meaning for most (if not all) of humanity. Some symbols, such as "updown", "light-darkness", "right-left", "blood", "circle or wheel", "world tree", "sky father - earth mother" are found again and again in cultures, remoted in space and time, that the existence of any historical influence or causal link between them would be incredible. Their universal distribution derives from the unity of the psychosomatic and social being of man. For example, all people are exposed to the physical law of gravity, and therefore it is usually harder to go up than down; this makes the natural association of the idea of ascending upward with the idea of attaining, as well as the association of different images that connote of height or elevation with the idea of superiority, and often the privileged class and power. Therefore, it is natural that they "make their way up" and not "make their way down". The king rules "over" his subjects, we prevail "over" circumstances and rule "over" temptations. A number of images tied up in a person's experience with the idea of "top" (such as a bird or an arrow flying through the air, a star, a mountain, a pillar, a tree that stretches upwards) have begun to mean (regardless of other values that may be inherent in the expression in a particular context) the subjects of aspirations and in a certain sense a blessing. Bottom in one of the two typical for this word types of contexts, tied with opposite connotations. We are "falling low", being exposed to bad habits, or are "at the bottom", becoming bankrupt, the flaws and poverty do not "uplift" us. The image of the abyss in religious symbolism, that is tied up with the idea of a sheer cliff, is reinforced by the fear of falling, the sudden loss of support, that is deeply hidden in a person. In the examples of symbolic creativity - religious and artistic - the "top" and "bottom" do not appear in their pure form, but often merge with other related ideas and images: with the light of divine wisdom on the one hand, and with the darkness of torment, loss and punishments on the other.

The archetypal symbol "blood" has a paradoxical nature. Its full semantic spectrum includes elements, mating with both good and evil, while the first is fairly light, and the second is relatively dark and that is why it is more sinister. The positive part of the meaning of "blood" is the connotation of life, hence the various kinds of power, including both physical strength and social status, which are inherited; hence the use of red paint for a long time, to provide things with miraculous power. At the same time, in many cases, the blood is tied to ominous content, turns it into a taboo, so it requires some respect, which can only be 
dealt with in exceptional cases and does not involve a scornful attitude. And since bloodshed is often tied to death, blood becomes a symbol of death.

The universal significance of water as an archetypal symbol is tied to its ability to purify in combination with the property of supporting life. Thus, water symbolizes both the purification and the beginning of a new life, and in the postulates of Christianity both of these ideas are combined: water in the rite of baptising symbolically cleanses from original sin and at the same time symbolizes the entry of the baptized one into the new spiritual life. Among the most significant archetypes the most perfect in the philosophical understanding is a circle, from its figurative concentration in the form of a wheel. Since ancient times, the circle is universally recognized as the most perfect of the figures, both because of its formal simplicity and because of the reason formulated in the aphorism of Heraclitus - in the circle, the beginning and the end belong to everyone. When a circle is concretized as a wheel, it gets two additional properties: it has spokes and rotates. The spokes of the wheel are perceived as an iconic symbol of the sun's rays; moreover, both the spokes and the rays symbolize the life force, which comes from some single source, which gives life and affects the whole world.

Like other archetypes, the wheel is potentially ambivalent. It may have a positive or negative significance, and sometimes both. On the negative side, in the West, the circle symbolized the perilous game of fate, and in the East - a continuous cycle of dying and rebirth, from which there is no salvation.

A very peculiar archetype is the word. A human is by nature a verbal one, a person who speaks and a person to whom he speaks has a word. As the ability of a person to reflect increases, the dialogue becomes internal and does not speak out loud, but this does not make it less real. Every person with a moral sense constantly feels himself as someone's addressee so he listens to some secret, silent voice, perceived by his inner ear. So, the word (Logos) has a tendency to become an aural image that symbolizes rightness, correctness, compulsion which gives meaning to the judgment of morality.

At the initial stage of development, the role of divine predictions was seen by people in certain sounds of nature: thunder rumble, wind noise etc. But gradually, as a person achieves higher spirituality, external noises as they are, stop playing the previous role, and the image-symbol of Logos, reflected in the statements "voice of conscience", "voice of God" or such a word as "vocation" comes into effect. The examples of archetypes or archetypal symbols we cited are fairly well known, since they are an arsenal of thinking and contemplation of each person and do not require additional clarification. They exist both in the arsenal of language and in the arsenal of the sensualfigurative re-creation of the world in the context of religion, art, science. One of the most outstanding artists and innovators of the twentieth century. S. Eisenstein, working on the problem of finding the visual arts of cinema, turned to Far Eastern hieroglyphics, on the one hand, and to the compositional principles of Far Eastern painting, on the other, in which the archetypal symbols were preserved in a more original form than in the European cultural tradition. These studies, that allowed him to understand the principle of mounting two or more images, form a new concept ("eyes" and "water", which can be depicted, will allow creating a graphic sign of the concept of "crying"), and the study of the Chinese "philosophy of numbers" built on spatial images and graphic images, rather than on abstract thinking, found that the composition of oriental painting is all saturated with the opposition "even-odd" [16, p. 234-278].
This study of S. Eisenstein formed the basis of his famous theory of mounting and laid the foundation for the theory of cinema. At the same time, it became one of the first attempts to apply the structural analysis of art, which makes it possible to refer $\mathrm{S}$. Eisenstein to the pioneers of modern semantics, the main problem of which is to study how the general human stock of concepts and images is expressed by installing them in each specific language or sign the system.

Conclusion. The original creativity made significant complexes of universal principles of the logic of building representations and images and on the basis of them a certain structure of language, with which further activity and opinion reached generalization and abstraction on an even higher level. The early, initial multi-stage human creativity completed the formation of dominant images, saw all the conditions of human existence, provided the products of the consciousness of completion, and became one of the most effective means of understanding the world. Thus, a certain structure of images was created and the structure of the language was developed on this basis.

The world of culture, like the world of nature, is structurally organized. But this structural organization is not and cannot be a simple reflection of the structure of nature. And just as without studying the structural organization of nature it is impossible to master it, to use and cohabit with it, so man cannot master his life without mastering cultural structures. Structuralism helps to live more consciously and "morally" in the world of culture.

\section{СПИСОК ВИКОРИСТАНИХ ДЖЕРЕЛ}

1. Антес Р. Мифология в Древнем Египте / Р. Антес // Мифология древнего мира - М.: Наука, 1977 - С. 33-87.

2. Арутюнова Н. Метафора и дискурс [Електронний ресурс] / Н. Арутюнова // Теория метафоры. - М.: Прогресс, 1990. - С. 5-33. Режим доступу: http://personal.pu.if.ua/depart/ihor.kozlyk/resource/file/pdf/ \%D0\%A2\%D0\%B5\%D0\%BE\%D1\%80\%D0\%B8\%D1\%8F\%20\%D0\%BC\%D \% \% $5 \%$ D1\%82\%D0\%B0\%D1\%84\%D0\%BE\%D1\%80\%D1\%8B.\%20\%D0\% A1\%D0\%B1\%D0\%BE\%D1\%80\%D0\%BD\%D0\%B8\%D0\%BA\%20\%D1\%81 \%D1\%82\%D0\%B0\%D1\%82\%D0\%B5\%D0\%B9.doc.pdf

3. Брунов Н. Памятники Афинского Акрополя. Парфенон и Эрехтейон / Н. Брунов. - М.: Искусство, 1973. - 176 с.

4. Вико Дж. Основания новой науки об общей природе наций [Електронний ресурс] / Дж. Вико. - М.-K.: Port-Royal, 1994. - Режим доступу: http://www.pseudology.org/History/Vico_Osnovaniya_Novoy_Nauki2.pdf

5. Гегель Г. Лекции по эстетике. Т. 1. [Електронний ресурс] Г. Гегель. - Режим доступу: https://esthetiks.ru/gegel-lektsii-po-estetike/ tom-1.html

6. Дьяконов И. Предисловие / И. Дьяконов // Мифология древнего мира. - М.: Наука, 1977. - С. 5-54.

7. Завадская Е. Эстетические проблеми живописи старого Китая / Е. Завадская. - М.: Искусство, 1975. - 440 с.

8. Кассирер Э. Сила метафоры [Електронний ресурс] / Э. Кассирер // Теория метафоры. - М.: Прогресс, 1990. - С. 33-44. - Режим доступу: http://personal.pu.if.ua/depart/ihor.kozlyk/resource/file/pdf/\%D0\%A2\%D0\%B $5 \% \mathrm{D} 0 \% \mathrm{BE} \% \mathrm{D} 1 \% 80 \% \mathrm{D} 0 \% \mathrm{~B} 8 \% \mathrm{D} 1 \% 8 \mathrm{~F} \% 20 \% \mathrm{D} 0 \% \mathrm{BC} \% \mathrm{D} 0 \% \mathrm{~B} 5 \% \mathrm{D} 1 \% 82 \%$ D0\%B0\%D1\%84\%D0\%BE\%D1\%80\%D1\%8B.\%20\%D0\%A1\%D0\%B1\%D0 \%BE\%D1\%80\%D0\%BD\%D0\%B8\%D0\%BA\%20\%D1\%81\%D1\%82\%D0\%B 0\%D1\%82\%D0\%B5\%D0\%B9.doc.pdf

8. Леви-Стросс К. Первобытное мышление / К. Леви-Стросс. - М.: Республика, 1994. - 354 с

9. Лосев А. Античний космос и современная наука / А. Лосев. - М.: Издание автора, 1927. - 56 с.

10. Маркс К. Экономически-фрилософсккие рукописи 1844 г. [Електронний ресурс] // Маркс К. Сочинения. т. 42. - Режим доступу: http://psylib.org.ua/books/marxk01/index.htm

11. Метафора в языке и тексте [Електронний ресурс]. - М.: Наука, 1988 - 176 с. - Режим доступу: https://www.twirpx.com/file/2023910/

12. Топоров В. Древо мировое: Мифы народов мира [Електронний ресурс] / В. Топоров // Энциклопедия в 2 тт. - Т. 1. - М.: Советская Энциклопедия. - 1980. - С. 398-406. - Режим доступу: http://pryahi.indeep.ru/mythology/research/drevo_mirovoe.html

13. Топоров В. Еще раз о древнегреческом слове гОФІА: происхождение слова, его внутренний смысл [Електронний ресурс] / B. Топоров // Структура текста. - Режим доступу: https://einai.ru/2013-02Toporov.html

14. Фрай Н. Анатомия критики [Електронний ресурс] / Н. Фрай // Зарубежная эстетика и теория литературы 19-20 вв. - М.: Издательство Московского университета, 1987. - Режим доступу http://readeralexey.narod.ru/ Library/Kosikov_Zarubezhnoye_literaturovedeniye_1987.pdf 
15. Эйзенштейн С. Чет-Нечет. Раздвоение единого / С. Эйзенштейн // Восток - Запад: Исследования. Переводы. Публикации. Вып. 3. - М.: Наука,1988. - С. 234-278.

\section{REFERENCES:}

1. Antes, R. (1977). Mifologija v Drevnem Egipte [Mythology in Ancient Egypt]. In Mifologija drevnego mira [The Mythology of the Ancient World], 33-87. Moskow, Nauka.

2. Arutjunova, N. (1990). Metafora i diskurs [Metaphor and Discourse]. In Teorija metafory [Theory of Metaphor]. Retrieved from http://personal.pu.if.ua/depart/ihor.kozlyk/resource/file/pdf/\%D0\%A2\%D0\%B 5\%D0\%BE\%D1\%80\%D0\%B8\%D1\%8F\%20\%D0\%BC\%D0\%B5\%D1\%82\% D0\%B0\%D1\%84\%D0\%BE\%D1\%80\%D1\%8B.\%20\%D0\%A1\%D0\%B1\%D0 \%BE\%D1\%80\%D0\%BD\%D0\%B8\%D0\%BA\%20\%D1\%81\%D1\%82\%D0\%B 0\%D1\%82\%D0\%B5\%D0\%B9.doc.pdf

3. Brunov, N. (1973). Pamjatniki Afinskogo Akropolja. Parfenon i Jerehtejon [Monuments of the Athenian Acropolis. Parthenon and Erechtheion]. Moskow, Iskusstvo.

4. Vico, G. (1994). Principles of a New Science Concerning the Nature of Nations. Retrieved from http://www.pseudology.org/History/ Vico Osnovaniya Novoy_Nauki2.pdf.

5. Hegel, G. (1964). Aesthetics. Lectures on Fine Art. Retrieved from https://esthetiks.ru/gegel-lektsii-po-estetike/tom-1.html.

6. D'jakonov, I. (1977). Predislovie [Preface]. In Mifologija drevnego mira [The Mythology of the Ancient World], 5-33 Moskow, Nauka.

7. Zavadskaja, E. (1975). Jesteticheskie problemi zhivopisi starogo Kitaja [Aesthetic Problems of Painting in Old China]. Moskow, Iskusstvo.

8. Cassirer, E. (1990). Sila metafory [The Power of Metaphor]. In Teorija metafory [Theory of Metaphor]. Retrieved from http://personal.pu.if.ua/ depart/ihor.kozlyk/resource/file/pdf/\%D0\%A2\%D0\%B5\%D0\%BE\%D1\%80\%
D0\%B8\%D1\%8F\%20\%D0\%BC\%D0\%B5\%D1\%82\%D0\%B0\%D1\%84\%D0\% BE\%D1\%80\%D1\%8B.\%20\%D0\%A1\%D0\%B1\%D0\%BE\%D1\%80\%D0\%BD \%D0\%B8\%D0\%BA\%20\%D1\%81\%D1\%82\%D0\%B0\%D1\%82\%D0\%B5\%D 0\%B9.doc.pdf

9. Lévi-Strauss, C. (1994). The Savage Mind. Moskow, Respublika. (In Russian).

10. Losev, A. (1927). Antichnij kosmos i sovremennaja nauka [Antiquny Space and Modern Science]. Moskow, Izdanie avtora.

11. Marx, K. (1973). Economic and Philosophic Manuscripts of 1844. Retrieved from http://psylib.org.ua/books/marxk01/index.html (In Russian).

12. Metafora $v$ jazyke $\mathrm{i}$ tekste [Metaphor in Language and Text]. Retrieved from: https://www.twirpx.com/file/2023910/

13. Toporov, V. (1980). Drevo mirovoe: Mify narodov mira [World tree: Myths of the Peoples of the World]. Retrieved from https://einai.ru/2013-02Toporov.html

14. Toporov, V. (1980). Eshhe raz o drevnegrecheskom slove $\Sigma O Ф I A:$ proishozhdenie slova, ego vnutrennij smysl [Once Again About the Ancient Greek Word "Sophia": The Origin of the Word, Its Inner Meaning]. In V. Toporov. Struktura teksta [The Structure of the Text]. Retrieved from https://einai.ru/2013-02-Toporov.htm

15. Fraj, N. (1987). Anatomija kritiki [Anatomy of Criticism]. In N. Frai. Zarubezhnaja jestetika i teorija literatury 19-20 cc. Moskow, Izdatelstvo Moskovskogo universiteta. Retrieved from http://readeralexey.narod.ru/ Library/Kosikov Zarubezhnoye literaturovedeniye 1987.pdf

16. Jejzenshtejn, S. (1988). Chet-Nechet. Razdvoenie edinogo [EvenOdd. Split of the One]. In Vostok - Zapad: Issledovanija. Perevody. Publikacii [East - West. Researches. Translations. Publications], 234-278, Vyp. 3. Moskow, Nauka.

Received Editorial Board 13.11.19

В. І. Панченко, д-р філос. наук, проф.

Київський національний університет імені Тараса Шевченка,

вул. Володимирська, 60, м. Київ, 01033, Україна

\section{МЕТАФОРА I МІФ ЯК ЕЛЕМЕНТИ ХУДОЖНЬОї МОВИ}

Стаття присвячена дослідженню зв'язку міфу і метафори як формотворчих елементів художньої мови. Художня культура виробила свої основні структурні елементи, які забезпечують певну логіку художнього мислення і художньої творчості і які закладені в основу будь-якого твору мистецтва. Ці структурні елементи - ритм, інтонація, метафора, міф (як спосіб організації дії, як прообраз композиції), архетипи й архетипічні символи - $є$ основними художніми засобами, які "працюють" у всіх видах мистецтва, одночасно визначаючи специфіку (за рахунок домінування) кожного $з$ них.

Ключові слова: міф, метафора, художня культура, структурні елементи, семіотика, художнє мислення.

В. И. Панченко, д-р филос. наук, профо

Киевский национальный университет имени Тараса Шевченко,

ул. Владимирская, 60, г. Киев, 01033, Украина

\section{МЕТАФОРА И МИФ КАК ЭЛЕМЕНТЫ ХУДОЖЕСТВЕННОГО ЯЗЫКА}

Статья посвящена исследованию связи мифа и метафоры как формообразующих элементов художественного языка. Художественная культура выработала свои основные структурные элементы, которые обеспечивают определенную логику художественного мышления и художественного творчества и которые заложены в основу любого произведения искусства. Эти структурные элементы - ритм, интонация, метафора, миф (как способ организации действия, как прообраз композиции), архетипы и архетипические символы - являются основными художественными средствами, которые "работают" во всех видах искусства, одновременно определяя специфику (за счет своего доминирования) каждого из них.

Ключевые слова: миф, метафора, художественная культура, структурные элементы, семиотика, художественное мышление.

Удк:316.7

О. Д. Рихліцька, канд. філос. наук, доц. Київський національний університет імені Тараса Шевченка, вул. Володимирська, 60, м. Київ, 01033, Україна o.rykhlytska@ukr.net

\section{ФЕНОМЕН МІСТА: СОЦІОКУЛЬТУРНІ ВИМІРИ}

У статті здійснюеться теоретичний та практичний аналіз сучасних підходів до вивчення міста та міської культури. Місто в дослідженні розуміється як особливий феномен, що онтологічно зумовлює форму і зміст культур в різноманітних проявах соціокультурної практики. Наводяться основні фактори, що впливають на розвиток міста та міської культури, а саме: глобалізаційні процеси, споживчий характер, гастрономічні символи та особливе значення механізмів культурної спадщини та навколишнього середовища. Стверджується, що формування міської ідентичності може відбуватися за кількома основними напрямками, які не збіеаються з напрямком консолідації спільнот, в контексті зростання поляризації та розриву комунікації між життєвим світом різних категорій міських жителів. Акцентується увага на невідворотних процесах у розвитку сучасних мегаполісів в цілому - спотворенні, відчуженні, техніцизмі та наслідках природоруйнівної сили. Продемонстровано досвід гармонійного конструювання міського середовища, практики його створення та вплив на міжлюдську взаємодію, що потребує соціокультурних перетворень.

Ключові слова: місто, міська культура, міський простір, урбанізм, екомісто, візуальна екологія.

Постановка проблеми. Останні десятиліття характеризуються міждисциплінарністю в різновекторних і досить неочікуваних зрізах, тому "міські дослідження", або "урбаністика", як цілісні феномени та інші важливі їхні елементи у сьогоденні $є$ предметом дослідження істориків, соціологів, мистецтвознавців, культурологів, архітекторів, дизайнерів, фольклористів, антропологів, що виступає незаперечним підтвердженням актуально- 